A R T I C L E S

\title{
Indo-European nominal $o$-stems and question of their origin
}

\begin{abstract}
Václav Blažek
Department of Linguistics and Baltic Studies, Faculty of Arts, Masaryk University, Brno blazek@phil.muni.cz
\end{abstract}

\begin{abstract}
Václav Blažek. Indo-European nominal o-stems and question of their origin. The Poznań Society for the Advancement of Arts and Sciences, PL ISSN 0079-4740, pp. 7-16

In the article the most productive formation of the Indo-European nominal declension, the $o$-stems, are described and analyzed. Two competing interpretations are discussed. One of them is finally preferred with respect to external typological parallels.
\end{abstract}

Keywords: Indo-European morphology, nominal declension, pronominal declension, ergative syntax, postpositive determination

1. The so-called thematic inflection is limited only to nouns extended by the vowel $-o$ - (with only exception in the voc. sg. in -e-), the so-called $\boldsymbol{o}$-stems. If it is not indicated otherwise, in the table 1 the continuants of the IE words *ull k" $k^{u} O-$ "wolf" and *iugó- "yoke" are cited (Table 1-2).

Table 1

\begin{tabular}{|c|c|c|c|c|c|c|c|c|c|}
\hline Singular & Vedic & Hittite & Greek & Latin & OIrish & Gothic & Lith. & OCS. & IE \\
\hline nom. & vŕkas & $\begin{array}{l}\text { ishäs } \\
\text { "lord" }\end{array}$ & $\lambda$ и́ко $\varsigma^{6}$ & lupus $^{14}$ & $\mathrm{fer}^{24}$ & wulfs $^{34}$ & vil̄kas & vlıkb & $*_{-o S}$ \\
\hline vok. & $v r k a^{1}$ & $i s h \check{a}$ & $\lambda$ & $\operatorname{lup} e^{15}$ & $f i r^{25}$ & wulf & vilke & vlbče & $*_{-e}$ \\
\hline acc. & vrikam & ishān & $\lambda$ Kov $^{7}$ & lupum $^{16}$ & $f e r^{26}$ & wulf $^{35}$ & vilkq $q^{40}$ & $v l b k b$ & *-om \\
\hline nom.-acc. n. & yugám & yugan & $\zeta v$ үóv ${ }^{8}$ & iugum $^{17}$ & scél $l^{77}$ & juk; ORun. horna "horn" & $\begin{array}{l}\text { Pr. } \\
\text { lunkan }\end{array}$ & igo & *-om \\
\hline gen. & v'́kasya & $i s h \overline{a s} s^{4}$ & $\lambda$ и́коюо ${ }^{9}$ & $\begin{array}{l}\text {-osio }^{18} \\
\operatorname{lupi}^{-19}\end{array}$ & $\begin{array}{l}\text { ?-oiso }{ }^{28} \\
\text { fir }^{29}\end{array}$ & $\begin{array}{l}\text { ORun. }-a s^{36} \\
\text { wulfis }^{37}\end{array}$ & $\begin{array}{l}\text { Pr. }-a s^{42} \\
=a b l\end{array}$ & $=\mathrm{abl}$. & $\begin{array}{l}* \text {-os } \\
*_{-o s-i o} \\
*_{-}-\bar{l}^{46}\end{array}$ \\
\hline abl. & vŕkād & antuhset ${ }^{5}$ & $e-k o-m e-n o^{10}$ & lup $\bar{o}^{-20}$ & CIb. $-u \partial^{30}$ & & vilkos ${ }^{43}$ & vlsk $k a^{42}$ & $\begin{array}{l}*_{-} \bar{o} d< \\
*_{-o}-e d^{47}\end{array}$ \\
\hline dat. & víkāya ${ }^{2}$ & $i s h \bar{\imath}$ & $\lambda v ́ \kappa \omega t^{11}$ & lup $\bar{o}^{21}$ & fiur $^{31}$ & ORun. $-a i^{38}$ & vil̃kui & vlъku & $*_{-} \bar{o} i<*_{-o-e i}$ \\
\hline loc. & vroke & $i s h \bar{\imath}$ & ойко1 ${ }^{12}$ & $\operatorname{dom} \vec{\imath}^{22}$ & CIb. $-e e^{32}$ & dat. wulfa & vilkè $e^{44}$ & vlacé & $*_{-}-o i<*_{-}-O-i$ \\
\hline inst. & vŕkena ${ }^{3}$ & & a-to-ro-qo ${ }^{13}$ & lup $\bar{o}^{-23}$ & CIb. $-u^{33}$ & dat. $w$ ulf $a^{39}$ & vilkù & vlrkomb $^{45}$ & $*_{-} o H_{1}<*_{-}-H_{l}$ \\
\hline
\end{tabular}

See Beekes 1995, 190-192; GHL 79-83; Szemerényi 1996, 182-188. 
Notes: 1) Absence of palatalization of the velar is explainable via paradigmatic levelling. 2) The final $-a$ is a particle (Beekes 1995: 192). 3) Adapted from the pronominal inflection, cf. the instr. sg. of demonstratives ena, téna, eténa, interrogative kéna, relative yéna, reflexive svéna (Macdonell 1916[2000]: 77, 106-112). 4) It corresponds to the gen. ending of other inflectional types. In the Luwian supbranch the genitive is replaced by so-called possessive adjectives, formed by the suffix -assi- in Cuneiform Luwian and -asi- in Hieroglyphic Luwian. Szemerényi (1996: 184, 187; following Mittelberger) derived them from the $o$-stem gen. in *-os-io. Melchert (2012) adds relics in Hittite, e.g. genušša/i- "knee(-joint)", šakuwašša- "deity of the eye". 5) The instr. sg. from antuhsas "man". The abl. sg. has the ending -az. 6) Cf. Myc. wo-no /woinos/ "vine". 7) Cf. Myc.

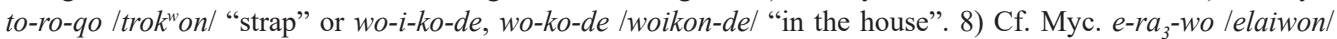
"olive oil". 9) Cf. Myc. do-e-ro-jo /do(h)elojjo/ "servant". 10) Myc. toponym, which may preserve the abl. sg.

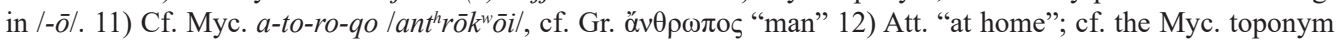
pu-ro /pulōil "in Pylos". 13) Myc. /ant ${ }^{h} r o \bar{k} k^{w} \bar{o} /$ (notes 6-13: see Bartoněk 2003: 188-210 \& Hajnal 1995: 23-24). 14) Cf. OLat. equos (Plautus), duenos (CIL I, 4), further Fal. Kaios, Ven. Voltiiomnos, Osc. húrz "grove", SPic. meitims "gift"? 15) Cf. Fal. Uoltene, Umb. Šerfe, Osc. Fatofe. 16) Cf. OLat. manom "hand", Fal. vinom "vine", Ven. ekvon "horse", Osc. húrtúm, dolom "intent", SPic. meitimúm. 17) Cf. OLat. donom "gift", Fal. duenom "good", Ven. donom \& donon "gift", osk. sakaraklúm, vol. pihom "of pious". 18) Cf. OLat. Popliosio Valesiosio = class. Lat. 'Publii Valerii' (Lapis Satricanus, 500 BC), Fal. Kaisiosio. 19) Cf. OLat. Aisclapi (CIL I, 440), argentī (Plautus) "of silver" (adj.), Fal. Marci, Ven. louki "of sacred grove". 20) Cf. OLat. fileod "to son", Osc. sakaraklúd "to sanctuary". 21) Cf. OLat. Numasioi duenoi, later Aiscolapio, Fal. Kaisioi, Ven. murtuvoi "to dead", Osc. húrtúi, SPic. brimeqlúi. 22) Lat. "in homeland", lit. "at home"; cf. Osc. húrtei. 23) In the form of the typ lupō three cases merged: dative, ablative \& instrumental sg.; cf. also Ven. instr. Voltiio (notes 14-23: see Meiser 1998: 134-135; UB 228-230). 24) Goid. *uiros "man"; cf. CIb. ueiðos "witness", Gl. tarvos "bull”, Lep. Alkouinos, Ulkos. 25) Goid. *uire, cf. Gl. (Lezoux) nate "oh, son!" (LG 143). 26) Goid. *uirom; cf. Clb. elaðunom, Gl. (Alise) celicnon "hall", but (Larzac) brictom "magic". 27) OIir. scél "message" < *sk"etlom (LEIA, S 39-40); cf. CIb. Belikiom, Lep. uinom "vine", Gl. (Chamalières) ollon "all", meion "small". 28) Lep. gen. sg. Xosioiso. Metathesis? 29) Goid. *uirī, Ogam maqqi "of son"; cf. Gl. (Couchey) Segomari, (Todi) Trutikni, Lep. Aśkoneti, but

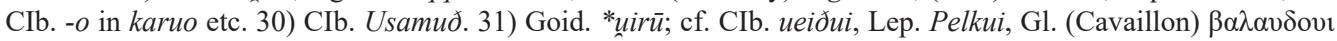
\& (Couchey) Alisanu. 32) CIb. kortonei, Gl. -e: uo duno derce "under the barrow", in Alixie "in Alesia". 33) CIb. auku, Gl. sunartiu "by good strength" (notes 24-33: see Lejeune 1971: 467; LG 51-56; MLH 396-400). 34) Cf. ORun. laukaz "garlic". 35) Cf. ORun. staina "stone". 36) ORun. Godagas. 37) Gmc. *-eso, adapted from the pronominal inflection, cf. Goth. his "what", pis "that", OCS. česo "what". 38) Cf. ORun. hahai. 39) Cf. the instr. sg. in OSas. dagu, OHG. tagu "by day". 40) Cf. Prus. deiwan "god". 41) Prus. "bast". 42) Prus. deiwas. 43) *-ād as in the $\bar{a}$-stems (cf. Szemerényi 1996: 183). 44) Diphthong remains petrified in some adverbs as Lith. namie "at home", Prus. bìtai "in the evening". 45) After other inflectional patterns (Erhart 1982: 120). The original ending, which should be *-a, may be fossilized in the interrogative \& relative OCS. adv. kogda, kbgda "when", if it is a compound of the pronominal root *ko-, *kb-, and the word god "time" (Wiedmann apud Brugmann 1911: 189). 46) Cf. also Alb. et "of father" < *attī : nom. atë; Toch. A Mahiśvari "Mahiśvari's", maybe also the genitive of kinship terms as A pācri, B pātri "of father" (Klingenschmitt 1992: 98-104). 47) Only the abl. sg. of the $o$-stems differs from the gen. sg., in other inflectional classes the gen. \& abl. sg. merge (with exception of Italic languages, Celtiberian and Anatolian languages, where the dental ablative was extended in other inflectional classes). Its origin has been sought in the pronominal ablative of the type Ved. mad, OLat. (also acc.) med (Praeneste), méd (Plautus), Fal. med, met, similarly OLat. ted \& sed, and perhaps Gl. *med \& *sed in the syntagms to-med-ec-lai (Voltino, North Italy), met-ingi-set-ingi "between me and between her" (Châteaubleau; see Lambert 2001: 112). The ending is identified with the particle $* a d<* H_{2} e d$ (Dunkel, Sihler etc.) or *eti $\sim *^{*}$ oti $<* H_{l}$ eti $\sim *^{*} H_{l}$ oti (Neu, Tichy etc.), see Szemerényi 1996, 187. 
Table 2

\begin{tabular}{|c|c|c|c|c|c|c|c|c|c|}
\hline Plural & Vedic & Hittite & Greek & Latin & OIrish & Gothic & Lith. & OCS. & IE \\
\hline nom. & vrkass & ishēs & $\lambda$ v́ко ${ }^{3}$ & $\begin{array}{l}\text { OU. }-u s^{9} \\
\text { lup }^{-10}\end{array}$ & $f i r^{16}$ & wulfos $^{24}$ & vilkai ${ }^{29}$ & vlaci & $\begin{array}{l}*_{-} \bar{o} s<*_{-o-e s} \\
*_{-o i}\end{array}$ \\
\hline acc. & vorkāan ${ }^{1}$ & EN.MEŠ-us & $\lambda$ v́кои $\varsigma^{4}$ & lupōs ${ }^{11}$ & $f i r u^{17}$ & wulfans & vilkùs $^{30}$ & vliky $y^{35}$ & $*_{\text {-oms }}$ \\
\hline nom.-acc. n. & yugáa & & $\zeta v \gamma \alpha^{5}$ & inga $^{12}$ & $\begin{array}{l}\text { scél }(a)^{18} \\
\text { CIb. - } a^{19}\end{array}$ & $j u k a^{25}$ & $\begin{array}{l}\text { Prus. } \\
\text { warto }^{31}\end{array}$ & iga & $*_{-}(e) \mathrm{H}_{2}$ \\
\hline gen. & vŕk $\bar{a} n \bar{a} m^{2}$ & $\begin{array}{l}\text { siunan } \\
\text { "of gods" } \\
\text { ishās }\end{array}$ & $\lambda{\operatorname{ló} \kappa \omega v^{6}}^{6}$ & lupōrum $^{13}$ & $f e r^{20}$ & $\begin{array}{l}-o /-a^{26} \\
\text { wulfe } e^{27} \\
\end{array}$ & vilkü $\tilde{u}^{32}$ & vlıkb & $*_{-}$- $\bar{m}<*_{-O-O m}$ \\
\hline dat.-abl. & vŕkebhyas & ishas & & - oibos $^{14}$ & $f e r(a) i b^{21}$ & wulfam $^{28}$ & vilkáms $^{33}$ & vlıkomb & $\begin{array}{l}\text { *-oi- }_{\text {- }}^{h} / m \text { - } \\
\text { *oi-os? }\end{array}$ \\
\hline loc. & vŕkeșu & ishas & $\lambda$ ${\cos \sigma \mathrm{l}^{7}}^{7}$ & $\operatorname{lupiss}^{15}$ & $-e i^{22}$ & & vilkuos $\dot{e}^{34}$ & vlıcěxъ & $*_{-o i-s u}$ \\
\hline inst. & vŕkais & & $\lambda$ v́коเऽ ${ }^{8}$ & lupiss $^{15}$ & $-u i s /-u s^{23}$ & & vilkaĩs & vlsk $y^{36}$ & $*_{-}-\check{O} \underline{a} i^{37}$ \\
\hline
\end{tabular}

See Beekes 1995: 192; Fortson 2004: 113-116; Szemerényi 1996: 183-88.

Notes: 1) Long $-\bar{a}$ - after the nom. pl. $-\bar{a} s$. Better is preserved the acc. pl. in OAv. mașsizōng, mașiiaqs-cā "man" (*"mortal") < *martianh, ${ }^{\circ a n s-c a ; ~ c f . ~ V e d . ~ m a ́ r t ~ y a ̄ n, ~ m a ́ r t ~ y a ̄ i m s ́-c a ~(H o f f m a n n ~ \& ~ F o r s s m a n ~ 1996: ~ 120) . ~ 2) ~ I n f l u-~}$ ence of the $n$-stems. The primary gen. pl. is preserved e.g. in the syntagm dévā $\tilde{n}$ janma "race of gods" (Szemerényi 1996: 185). 3) Cf. Myc. o-no /onoil "donkeys". 4) The ending of the acc. pl. is preserved in Arg. vióv "sons";

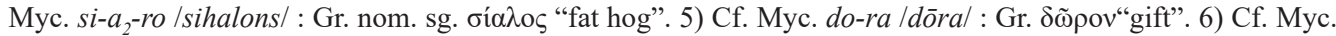

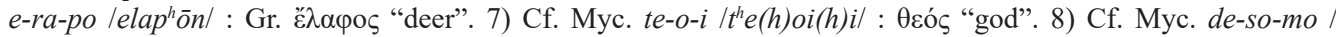

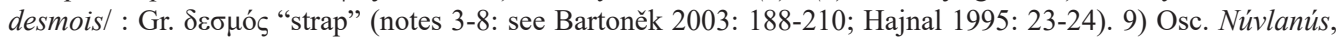
SPic. Safinús, Umb. Ikuvinu. 10) Cf. OLat. peploe, besides epigraphic Virei. 11) Cf. OLat. deivos, Ven. deivos, Osc. feíhúss, Umb. vitluf. 12) Cf. Umb. iuku \& iuka. 13) Adapted from the pronominal inflection: ${ }^{\circ} \overline{o r u m}<*_{-}$ussom

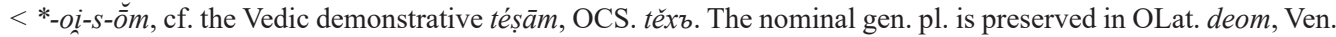
Oterginon, Pael. Cerfum, CPic. Safinúm, Osc. Núvlanúm. 14) Ven. ekvoibos, besides louderobos. 15) In Lat. the dat.-abl. pl. of $o$-stems in -is merged with two other cases, the loc. pl. in *-oi-su, and instr. pl. in *-ois. The diphthong is also preserved in OLat. qurois, poplois, Pael. puclois, Osc. feíhúís, zicolois (notes 9-15: see UB 229-230).

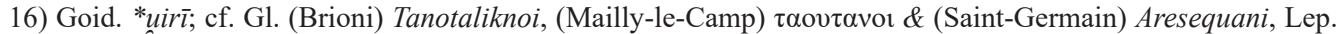
Kasiloi, Clb. Alaboi. The original nom. pl. in *-ōs was preserved in OIrish voc. pl. firu < Goid. *uirüs. 17) Goid.

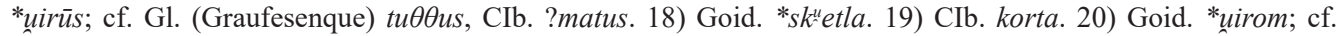
Gl. (Chamalière) diiiuion \& ande-dion, CIb. Titum. 21) Goid. *uiro[i]bi(s) (Thurneysen 1946: 182) with the ending *-bi(s), corresponding to the Gl. instr. pl. gobedbi, cf. dat. pl. in Gl. Rudiobo, Lep. Uvltiauobos, CIb.

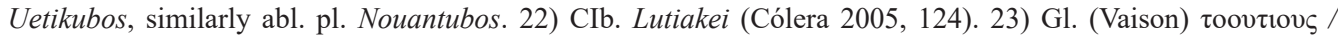
(Graufesenque) Vindulus. 24) The pronominal nom. pl. in -ai appears in the Gothic strong adjective nom. pl. m. blindai "blind". Further cf. ORun. arbijarjostez "most legitimate-to-inherit”?, besides later stAinAz "stones", ON. ulfar "wolves". 25) Cf. ORun. hag lu "hail" : nom. sg. n. hagala. 26) ORun. Wiwio, later flAinA, ON. daga, OEng. decga, OSax. dago "days" $\left.<*_{-} \bar{o}^{n} .27\right)$. The Gothic gen. pl. m./n. in -e instead of expected ${ }^{+}-o$ had perhaps to eliminate homonymy with the gen. pl. f. (Brugmann 1911: 238-239; Ringe 2006: 282). Kortlandt apud Beekes (1985: 142) explains $-e$ from Gmc. ${ }^{*}-\bar{e}<*_{-}^{*} e-$-om , thus from the gen. pl. $i$-stems, whence the ending had to spread. 28) Cf. ORun. borumz "to sons". Kortlandt (apud Beekes 1985: 144) explains the vowel $u$ in the OHG. dat. pl. tagum via the $u$-umlaut caused by vocalization of the ending *-mus (notes 23-27: see Antonsen 1975: 18-19). 29) Cf. Prus. wijrai "men". 30) Lith. -us < *-uos < *-ons (Otrębski III, 16). Cf. Prus. deiwans "gods". 31) Prus. "doors". 32) Cf. Prus. grīkan : nom. sg. grīkas "sin". 33) Cf. OLith. [Daukša's Postilla] waykâmus = Lith. vaikáms "to children". 34) The Lith. ending to loc. pl. could originate in contamination with the acc. pl. *-uons and

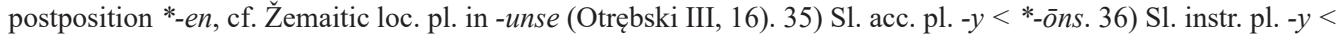
*oōis (Erhart 1982: 121). 37) The instr. pl. in *-ois (Gr., It., Balt.) or *-ois (II., Celt., Sl.) remains non-transparent. Maybe, it is the instr. sg. in $*_{-}-H_{1}$ extended by non-singular $*_{-o i}$ - and pluralizing $-s$ (otherwise Erhart 1982: 98; Szemerényi 1985: 519-520).

Besides the singular and plural the Indo-European protolanguage also differentiated the dual, although this category was not preserved in all daughter branches. E.g. in old literary Germanic languages the dual disappeared from the nominal morphology, but remained in the pronominal and verbal systems. In Latin the traces of the dual are preserved only in the 
numerals duo (duō by Plautus), duae, duo "two", and ambō, -ae,-o "both". In the Anatolian branch the traces of dual have been sought in designations of the pair body parts, e.g. Hitt. sakuwa "eyes", Luw. aruta "wings", issara "hands", pata "feet" (Krasuxin 2004: 133; Szemerényi 1996: 161). Thanks to homonymy of endings the dual paradigm is less rich in comparison with plural even in those languages, where the dual was preserved (Table 3 ).

Table 3

\begin{tabular}{|c|c|c|c|c|c|c|c|}
\hline Dual & Vedic & Avestan & Greek & Old Irish & Lith. & OCS. & $\mathrm{IE}$ \\
\hline nom.-acc. m.f. & vŕkā, vŕkau & $s p \bar{a} d \bar{a}^{3}$ & $\lambda \hat{v} \kappa \omega^{7}$ & fer $<$ *uirā & vilkù & vlbka & $*_{-}--_{1}$ \\
\hline nom.-acc. n. & yugé & śiiao $\theta n \bar{o} i^{4}$ & $\zeta v \gamma \omega^{8}$ & $s c e ́ l^{11}$ & & $i(d) z \check{e}$ & $*_{-}-\mathrm{-iH}$ \\
\hline gen. & $=1 \mathrm{loc}$. & ${\text { aqsaiii } \bar{a}^{5}}^{5}$ & $=$ loc. & fer < *uirou & dvíejaus $^{12}$ & $=$ loc. & $*_{-o i}-H_{l} \bar{o} s$ \\
\hline loc. & vŕkkayos ${ }^{1}$ & zastaii $^{6}$ & $\lambda$ и́коuv ${ }^{9}$ & & dvíejau $^{12}$ & vlbku & 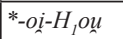 \\
\hline dat.-abl.-inst. & $\begin{array}{l}\text { vŕkābhyām } \\
\text { aśvebhyām }{ }^{2}\end{array}$ & $\begin{array}{l}\text { zastōibiii } \bar{a}^{6} \\
\text { aspaēbii } \bar{a}^{2}\end{array}$ & & $\begin{array}{l}\text { fer }(a) \text { ib }< \\
\text { *uirobim }\end{array}$ & vilkám & vlıkoma & $\begin{array}{l}* \text {-oin-b } \mathrm{b}^{\mathrm{h}} \mathrm{ioH} \\
*_{\mathrm{l}} \mathrm{o}-\mathrm{moH}_{1}\end{array}$ \\
\hline instr. & & & $o-m o-p i^{10}$ & & 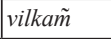 & & $*_{-} \mathrm{o}-\mathrm{b}^{\mathrm{h}} / \mathrm{miH}_{1}$ \\
\hline
\end{tabular}

See Beekes 1995: 194-195; Brugmann 1911: 282-283; Hoffmann \& Forssman 1996; Szemerényi 1996: 183-185. Notes: 1) *-oi-H $H_{1}$ ou + -s perhaps after the gen. 2) "horse". 3) OAv. spāda- "army". 4) OAv. šiiaoOna- "action", cf. YAv. saite "200", duiie, duuaē-ca "2". 5) OAv. asa- "share". 6) OAv. zasta- "hand". 7) Cf. Myc. po-ro /pōlō/ "two foals". 8) Ending of the m.-f. du. 9) Rix (1976, 141): *-oisin after the dat.-loc. pl. *-oisi with the final nasal after the instr. du. *oi- $b^{h} i m$; otherwise Beekes (1995: 195): *-oi-Hu-m? 10) Myc. /oimophil : Gr. oĩuo "bundle" (Hajnal 1995: 23). 11) It causes a nasalization of the following initial: maybe an identification with the ending of the nom. sg. n. *-om. More original is perhaps Gl. uercobreto (Thurneysen 1946: 182). 12) Lith. dveji "double".

2. Origin of the $o$-stems was discussed many times. Two hypotheses seem best argumented. 2.1. Pedersen (1907: 152) mentioned that the subject of transitive verb looks like in genitive (sigmatic case), if was active, and like in instrumental, if was inactive. On the other hand, the subject of intransitive verb and object of transitive verb were in absolutive (i.e. asigmatic) case. This asymmetry between valency of transitive and intransitive verbs is summarized in Tab 11 (see Beekes 1995, 193) (Table 4).

Table 4

\begin{tabular}{c|l|l|l}
\hline \multicolumn{1}{c|}{ Verb } & & Nominative system & \multicolumn{1}{c}{ Ergative system } \\
\hline \multirow{2}{*}{ transitive verb } & subject & nominative & ergative \\
\cline { 2 - 4 } & object & accusative & absolutive \\
\hline intransitive verb & subject & nominative & absolutive \\
\hline
\end{tabular}

Beekes (1985: 191-195; 1995: 193) and Kortlandt (2002: 217) develop Pedersen's idea, assuming that the nominative syntax of old Indo-European languages was formed later and the case system of the Indo-European protolanguage is primarily based on the ergative syntaxis. The same ending of the nom. and acc. neuter designating originally inactive nouns originated from the primary absolutive, while the ergative belonged to the active subject. According to Beekes the sigmatic genitive-ablative developed from the ergative. During transformation of the ergative system into nominative one the form reconstructed as $C C$-R-ós became the nominative, a new case of subject. The vowel - $O$ - had spread to other cases. Schmalstieg (1997: 401-407) and Gamkrelidze \& Ivanov (1984: 267-91: active typology) formulated their own theories assuming the ergative past of the IE syntax. 
The implications of the ergative interpretation:

\section{Table 5}

\begin{tabular}{|c|c|c|}
\hline Case & Form $^{(*)}$ & Comments in perspective of the ergative interpretation \\
\hline \multirow[t]{3}{*}{ sg. nom. } & $-\varnothing$ & in HD inflection and PD neuters (B 1985: 172) \\
\hline & $-s \quad$ act. & identical with the sigmatic gen.-abl. sg., originally ergative (B 1985: 172-195) \\
\hline & -om inact. & agens of the transitive verb (Pedersen 1907: 152; Schmalstieg 1997: 405-406: instr. of $o$-stems) \\
\hline voc. & $-\varnothing$ & see B 1985: 99-108 \\
\hline acc. & $-m$ & originally directive-terminative (B 1985: 198) \\
\hline gen. & $-(o) s$ & originally ergative (B 1985, 172-95); in Hitt. used in both gen. sg. \& pl. \\
\hline$(o-$ & -osio & $<$ gen. $*_{\text {-os } \& \text { relative }} *_{\text {io }}(\mathrm{B}$ 1985: 185; Nikolaev 2000) \\
\hline stems) & $-\bar{l}$ & cf. the suffix of affiliation *-iio- (*-iHo-?); see K 1994: 98-104; Meiser 1998: 135 \\
\hline abl. & $-O S$ & identical with the gen. sg. in *-(o)s, originally the ergative (B 1985: 172-195) \\
\hline$(o$-st.) & $-(o / e) t / d(i)$ & cf. also Hitt. $-a z$ \\
\hline dat. & $-(e) i$ & on persons; dat. \& loc. were originally one and the same case (B 1995: 173) \\
\hline loc. & $-i$ & $\begin{array}{l}\text { on places \& inactive nouns; originally identical with the dative (B 1995: 173); cf. Arm. herow, } \\
\text { Gr. } \pi \dot{\rho} \rho \sigma^{\prime}(v) \text {, ON. i fjord "last year", OIr. ón n-urid "from last year" < *per-uti "year ago" }\end{array}$ \\
\hline instr. & $-H_{1}$ & cf. instr. pl. of the $o$-stems $*_{-} \bar{o} i s<$ instr. sg. $*_{-} o H_{1}+$ non-singular $*_{-o i-}+$ pluralizing $-s$ \\
\hline pl. nom. & -es & \\
\hline$(o-$ & $-o i$ & plural of pronominal origin \\
\hline \multirow[t]{2}{*}{ stems) } & $-O i-$ & non-singular affix of the $O$-stems, preceding the case ending \\
\hline & $-H_{2}$ inact. & collective \\
\hline voc. & $=$ nom. & \\
\hline acc. & $-m s$ & $=$ acc. sg. $-m+$ pluralizing $-s$ in congruence to the nom. pl. in $-e s$ \\
\hline gen. & $-o m$ & see Kortlandt 1978; in Hitt. used in both gen. sg. \& pl.; Schmalstieg 1997: 405-406: ergative \\
\hline abl. & $-i o s$ & $>$ Arm. $-\check{j}$, II. $*-b^{h}(i)-i{ }^{\prime} O S$ \\
\hline dat. & $-m u s$ & $>$ BSl. *-mus; Gmc. *-muz \\
\hline loc. & $-s u \sim-s i$ & $\begin{array}{l}\text { cf. Lat. mox, MWelsh moch "soon"< *mok-su; Alb. abl. pl. -sh: malesh "in mountains"; për-posh } \\
\text { "down", posh-të "below": " posh }{ }^{\circ}<* p \bar{e} d-s i \text {; Phryg. } \tau \varepsilon v \tau \omega \sigma \mathrm{l} \text { "in villages" (K 1994: 313; H 2003: 129) }\end{array}$ \\
\hline instr. & $-b^{h} i$ & 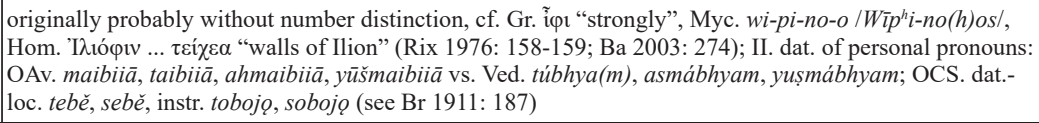 \\
\hline
\end{tabular}

$\mathrm{B}=$ Beekes; $\mathrm{Ba}=$ Bartoněk; $\mathrm{Br}=$ Brugmann $; \mathrm{H}=$ Hajnal; $\mathrm{K}=$ Klingenschmitt.

Note: Identification of non-singular morpheme *-oi- and pluralizing $-s$ imply in some cases the agglutinative structure.

2.2. Jean Haudry (1982: 36-38) formulated the idea that the $o$-stems originated from pronouns with determining function added to a nominal base, playing so a role of a postpositive article. For this solution there are typological parallels e.g. in Balto-Slavic languages, where the adjectives used in the attributive role are extended by the IE relative $*_{i o}-{ }^{*}{ }_{i} \bar{a}-$, the postpositive determination using demonstratives is living in modern Balkanian or Scandinavian languages. So-called mimation \& nunation in Semitic languages also represent in principle the postpositive determination. In Indo-European a good candidate could be identified in the Anatolian pronoun - $a$ - of the 3rd person attested only in postposition (HEG 1-2: 6-7) (Table 6). 
Table 6

\begin{tabular}{|c|c|c|c|c|c|c|}
\hline Case & Hittite & Palaic & C. Luwian & Hier. Luwian & Lydian & * \\
\hline nom. sg. c. & -as & -as & $-a s$ & $-(a)_{s}$ & $-a s ́$ & $*_{-} O S$ \\
\hline nom.-acc. sg. n. & $-a t$ & $-a t$ & $-a t a$ & $-(a) t a$ & $-a d,-a t$ & *-ot \\
\hline acc. sg. c. & -an /-un & $-a n$ & $-a n$ & $-a n$ & $-a v$ & *-om \\
\hline nom. pl. c. & $-e$ & -as & & & & $*_{-o i}$ \\
\hline nom.-acc. pl. n. & $-e$ & $-e$ & & & & $*_{-o i}$ \\
\hline acc. pl. c. & $-u s$ & & & & & *-oms \\
\hline acc. pl.n. & $-a t$ & & $-a t a$ & $-(a) t a$ & & $*$-ot \\
\hline
\end{tabular}

3. Summarizing the preceding partial reconstructions, it is apparent, most difficult is to establish the original protoforms of the ablative, dative and instrumental plural. It is natural to suppose mutual levelling, merging, interference. These processes are concentrated to Table 7 (see Brugmann 1911: 120; Beekes 1985: 144-146), whence the following case protosystem may be postulated (Table 7), to explain the partial case systems in daughter branches.

Table 7

\begin{tabular}{|c|c|c|c|c|c|c|c|c|c|}
\hline case & IE & II & Arm. & Gr. & Messap. & Italic & Celtic & Gmc. & BS1. \\
\hline dat. pl. & *-mus & & & & & & & & *-mus \\
\hline$>$ & & & & & & & & $*_{-m o s}$ & \\
\hline abl. pl. & $*_{-i o s}$ & & $-j^{2}$ & & & & & & \\
\hline$>$ & & $*-b^{h} i o s$ & & & $-b i s^{3}$ & $*_{-} b^{h} O S$ & $*_{-} b^{h} O S$ & & \\
\hline ins. pl. & $*-b^{h} i^{1}$ & $*_{-} b^{h} i s$ & ${ }^{*}-b^{h} i(s)$ & ${ }^{*}-b^{h} i$ & & & $*-b^{h} i(s)$ & & \\
\hline$>$ & & & & & $-b a s^{4}$ & & $*-m i^{5}$ & ${ }^{*}-m i s^{6}$ & ${ }^{*}-m i H s$ \\
\hline dat. pl. & *-mus & & & & & & & & \\
\hline
\end{tabular}

Notes: 1) Probably the same suffix appears in Hitt. kuwapi “where, when” (HEG 4: 229-232). 2) Arm. - $y$ in the abl. pl. of personal pronouns mēnj, jēnj is derivable from *-ios (Kortlandt 1984: 103-104 = 2003: 50; Beekes 1985: 144). 3) Messap. abl. pl. ogrebis, tatӨebis, valeabis (see MLM II). 4) Messap. dat. pl. Laidehiabas, Logetibas. 5) Cf. the OIr. dat. pl. $n$-stems of the type anm(a)imm from ainm "name" (already Brugmann 1911: 188 thought about this solution and Hamp 1996 returned to it). 6) See WGmc. dat. pl. Vatvims \& Aflims, corresponding to Lat. Vatviabus \& Afliabus, and OEng. dat. pl. đōem from the demonstrative $s \check{\bar{e}}$ "that" with the $i$-umlaut (Brugmann 1911: 262, 264).

Table 8

\begin{tabular}{|c|c|c|c|c|c|c|}
\hline \multirow{2}{*}{$\begin{array}{c}\text { Number } \\
\text { case / type }\end{array}$} & \multicolumn{2}{|c|}{ Singular } & \multicolumn{2}{|c|}{ Plural } & \multicolumn{2}{|c|}{ Dual } \\
\hline & athematic & thematic & athematic & thematic & athematic & thematic \\
\hline nom. anim. & $*_{-s}$ & $*_{-o S}$ & *-es & $*_{\text {-oss }}<*_{\text {-o-es }}$ & $*_{-} H_{1}$ & $*_{-o-H_{1}}$ \\
\hline voc. & $*_{-\varnothing}$ & $*_{-} e$ & *-es & $*_{-} \overline{o s}<*_{-o-e s}$ & $*_{-} H_{1}$ & $*_{-} \mathrm{O}-\mathrm{H}_{1}$ \\
\hline acc. anim. & ${ }^{*}-m$ & *-om & ${ }^{*}-m s$ & *-oms & $*_{-} H_{1}$ & $*_{-O}-H_{1}$ \\
\hline nom.-acc. n. & $*_{-\varnothing}$ & *-om & $*-H_{2}$ & $*-e H_{2}$ & $*_{-i H_{1}}$ & $*_{-o-i H_{I}}$ \\
\hline gen. & $*_{-S}$ & $*-o s(-i o)$ & *-om & *-ōm & ${ }^{*}-H_{l} \overline{o s}$ & ${ }^{*}-o i-H_{I} \bar{o} s$ \\
\hline abl. & $*_{-S}$ & $*_{-} \bar{o} d<*_{-o-e d}$ & $*_{-i o s}$ & *-OI-OS $_{\sim}$ & $=$ dat. & $=$ dat. \\
\hline dat. & $*_{-e i}$ & $*_{-} \bar{o} i<{ }^{*}{ }_{-}-O-e i$ & *-mus & *-oi-mus & $*_{-}-m \bar{o} H_{1}$ & *-oi-mō $H_{I}$ \\
\hline loc. & $*_{-i}$ & $*_{-}-o i$ & $*_{-s u}$ & *ol-su & $*_{-} H_{l} \mathrm{ou}$ & *-oi- $\mathrm{H}_{I} \mathrm{Ou}$ \\
\hline instr. & $*_{-} H_{l}$ & $*_{-}-H_{1}$ & ${ }^{*}-b^{h} i(s)$ & ${ }^{*}$-oi- ob $^{h} i(s)$ & ${ }^{*}-b^{h} i H_{l}$ & $*_{-o i-b^{h} i H_{I}}$ \\
\hline
\end{tabular}

See Beekes 1995: 173; Fortson 2004: 113.

4. A little surprising typological and structural argument supporting one of the preceding solutions may be found outside the Indo-European language family. In the Uralic protol- 
anguage the nominative has been reconstructed as unmarked. But in several Fenno-Ugric languages a specific nominative was formed from demonstratives or demonstrative suffixes of the 3rd person according to the scenario described by Haudry in connection with the IE $o$-stem nominative in $*_{-S}(\S 2.2$.) (Table 9).

Table 9

\begin{tabular}{l|l|l|l|l|l}
\hline \multicolumn{1}{c|}{ Language } & \multicolumn{1}{c|}{ indet. sg. } & \multicolumn{1}{c|}{ det. sg. } & \multicolumn{1}{c}{ indet. pl. } & \multicolumn{1}{c}{ det. pl. } & \multicolumn{1}{c}{ origin of suffix } \\
\hline Mordvin & tolga "feather" & tolgaś "that f." & tolgat "feathers" & tolgat'n̈ "those f." & śä, śe "that" : ńe "these" \\
\hline Udmurt & iz "stone" & izez "that s." & izjos "stones" & izjosiz "those s." & $-z$ suffix of 3rd person sg. \\
\hline Komi & vok "brother" & vokis "that b." & vokjas "brothers" & vokjasiz "those b." & $-s$ suffix of 3rd person sg. \\
\hline
\end{tabular}

See Szinnyei 1910: 62.

Summing up, from both competing hypotheses described in \$2.1. and 2.2. the latter solution operating with postpositive determination seems more probable, since is supported by external typological parallels.

\begin{abstract}
Abbreviations
ab(1). ablative, abs. absolutive, adj. adjective, adv. adverb, advr. adverbialis, Aeol. Aeolic, acc. accusative, Alb. Albanian, act. active, Arg. Argive, arch. archaic, Arc. Arcadian, Arm. Armenian, Att. Attic, Av. Avestan, Balt. Baltic, Bret. Breton, BSl. Balto-Slavic, c. genus communis, C. Cuneiform, Celt. Celtic, Clb. Celtiberian, Cl. Classic, col. collective, com. comitative, cons. consonantic, Corn. Cornish, Cret. Cretan, Cz. Czech, dat. dative, det. determined, dir. directive, Dor. Doric, du. dual, E East, Eng. English, ep. epigraphic, erg. ergative, f. feminine, Fal. Faliscan, Fi. Finnish, fin. finalis, FU. Fenno-Ugric, Ge. Georgian, gen. genitive, Gl. Gaulish, Gmc. Germanic, Goid. Goidelic, Goth. Gothic, Gr. Greek, heter. heteroclitic, Hier. Hieroglyphic, Hitt. Hittite, Hom. Homeric, id. idem, IE Indo-European, II. Indo-Iranian, inact. inactive, indet. indetermined, ins(tr). instrumental, Ir. Irish, It. Italic, Lat. Latin, Latv. Latvian, Lep. Lepontic, Lesb. Lesbian, Lith. Lithuanian, loc. locative, Luw. Luwian, Lyd. Lydian, Lyc. Lycian, m. maskuline, M Middle, Marr. Marrucine, Mars. Marsian, Messap. Messapic, Myc. Mycenaean, n. neuter, N North, nom. nominative, O Old, obl. oblique, OCS. Old Church Slavonic, OHG. Old High German, ON. Old Nordic (incl. Old Icelandic), ORun. Old Runic, Osc. Oscan, OU. Oscan-Umbrian, p- proto-, Pael. Paelignian, Phryg. Phrygian, Pic. Picenian, pl. plural, Pr(us). Prussian, pred. predicative, S South, sg. singular, Skt. Sanskrit, Sl. Slavic, soc. sociative, suf. suffix, Sx. Saxon, Syr. Syriac, term. terminative, Toch. Tocharian, tran. transformative, Umb. Umbrian, Ved. Vedic, Ven. Venetic, voc. vocative, Vol. Volscan, W West, Y Young.
\end{abstract}

\title{
Acknowledgements
}

The present study was prepared thanks to the grant of the The Czech Science Foundation (GAČR), GA15-12215S.

\section{References}

Adams, Douglas Q. 1999. A Dictionary of Tocharian B. Amsterdam-Atlanta: Rodopi.

Antonsen, Elmer. 1975. A Concise Grammar of the Older Runic Inscriptions. Tübingen: Niemeyer.

Bader, Françoise. 1991. Problématique du génitif thématique sigmatique. Bulletin de la Société de Linguistique de Paris 86(1). 89-157.

Beekes, Robert S. P. 1985. The Origins of the Indo-European Nominal Inflection. Innsbruck: IBS 46.

Beekes, Robert S. P. 1995. Comparative Indo-European Linguistics. An Introduction. Amsterdam-Philadelphia: Benjamins. 
Blažek, Václav. 1999. Numerals. Comparative-etymological analyses and their implications. Brno: Masarykova univerzita.

Blažek, Václav. 2010. Indoevropská substantivní deklinace [Indo-European declension of substantives]. Linguistica Brunensia 58(1-2). 51-91.

Brockelmann, Carl. 1908. Grundriss der vergleichenden Grammatik der semitischen Sprachen, Vol. I: Laut- und Formenlehre. Berlin: Reuther \& Reichard.

Brugmann, Karl. 1906/1911. Grundriss der vergleichenden Grammatik der indogermanischen Sprachen, II.1/2. Strassburg: Trübner.

Cólera, Carlos Jordán. 2005. Celtibérico. Zaragoza: Gorfisa.

Elizarenkova, Tat'jana Ja. 1987. Vedijskij jazyk. Moskva: Nauka.

Erhart, Adolf. 1982. Indoevropské jazyky. Srovnávaci fonologie a morfologie. Praha: Academia.

Erhart, Adolf. 1993. Die indogermanische Nominalflexion und ihre Genese. Innsbruck: IBS 73.

EWAI = Mayrhofer, Mannfred 1986n. Etymologisches Wörterbuch des Altindoarischen, I-III. Heidelberg: Winter.

Gamkrelidze, Tamas V. \& Ivanov, Vjačeslav V. (1984). Indoevropejskij jazyk i indoevropejcy. Tbilisi: Izdatel'stvo Tbilisskogo universiteta. In English: Indo-European and the Indo-Europeans: a reconstruction and historical analysis. Berlin 1995: Mouton de Gruyter.

GHL $=$ Hoffner, Harry A. jr. \& Melchert, H. Craig. 2008. A Grammar of Hittite Language, Part 1: Reference Grammar. Winona Lake: Eisenbrauns.

Hajnal, Ivo. 1995. Studien zum mykenischen Kasussystem. Berlin-New York: Walter de Gruyter.

Hajnal, Ivo. 2003. Methodische Vorbemerkungen zu einer Palaeolinguistik des Balkanraums. In Bammesberger, Alfred \& Vennemann, Theo (eds.), Languages in Prehistoric Europe, 117-145. Heidelberg: Winter.

Hamp, Eric P. 1979. Indo-European * $g^{w} e n-H_{a}$. Zeitschrift für vergleichende Sprachforschung 93. 1-7.

Hamp, Eric P. 1981. Indo-European * $\left(H_{e}\right)$ op-. Münchener Studien zur Sprachwissenschaft 40. 39-60.

Hamp, Eric P. 1987. Varia. Études Celtiques 24. 185-189.

Hamp, Eric P. 1994. The Laryngeal Heteroclites. In Bielmeier, Roland \& Stempel, Reinhard (eds.), Indogermanica et Caucasica. Festschrift für K.H. Schmidt zum 65. Geburtstag, 35-40. Berlin-New York: Walter de Gruyter.

Hamp, Eric P. 1996. Varia II: 1. On the Old Irish dat. sg. in ${ }^{*+} m i$. Ériu 47. 209.

Haudry, Jean. 1982. Prehistoire de la flexion nominale indo-européenne. Lyon: Institut d'études indo-européennes de l'Université Jean Moulin (Lyon III).

HEG = Puhvel, Jaan. 1984n. Hittite Etymological Dictionary. Berlin-New York: Mouton de Gruyter.

Hoffmann, Karl \& Forssman, Bernhard. 1996. Avestische Laut- und Flexionslehre. Innsbruck: IBS 84.

Klingenschmitt, Gerd. 1992. Die lateinische Nominalflexion. In Panagl, Oswald \& Krisch, Thomas (eds.), Latein und Indogermanisch. Akten des Kolloquiums der Indogermanischen Gesellschaft (Salzburg, Sept. 1986). Innsbruck: IBS 64, 89-135.

Klingenschmitt, Gerd. 1994. Das Tocharische in indogermanischer Sicht. In Schlerath, B. (ed.), Tocharisch (Akten des Fachtagung der Indogermanischen Gesellschaft, Berlin, sept. 1990), 310-411. Reykjavík: TIES Suppl. Series, Vol. 4.

Kortlandt, Frederik. 1978. On the history of the genitive plural in Slavic, Baltic, Germanic, and Indo-European. Lingua 45. 281-300.

Kortlandt, Frederik. 1984/2003. Proto-Armenian case endings. In International symposium on Armenian linguistics. Erevan: Akademija nauk Armjanskoj SSR, 97-106 / Armeniaca. Ann Arbor: Caravan Books, 45-56.

Kortlandt, Frederik. 2002. The Indo-Uralic Verb. In Finno-Ugrians and Indo-Europeans: Linguistic and Literary Contacts. Proceedings of the Symposium at the University of Groningen (Nov. 2001). Maastricht: Shaker (Studia Fenno-Ugrica Groningana 2), 217-227.

Krahe, Hans. 1948. Historische Laut- und Formenlehre des Gotischen. Heidelberg: Winter.

Krasuxin, Konstantin G. 2004. Vvedenie v indoevropejskoe jazykoznanie. Moskva: Akademija.

Kulikov, Leonid. 2009. Evolution of Case Systems. In Malchukov, Andrej \& Spencer, Andrew (eds.), Oxford Handbook of Case. Oxford: University Press, 439-457.

Lambert, Pierre-Yves. 2001[1998-2000]. La tuile de Châteaubleau (Seine-et-Marne). Études celtiques 34. 57-115.

LEIA = Joseph Vendryes \& Pierre-Yves Lambert. 1959-96. Lexique étymologique de l'irlandais ancien. Dublin: Institute for Advanced Studies - Paris: CNRS Éditions.

Lejeune, Michel. 1971. Lepontica. Études celtiques 12. 356-500.

$\mathrm{LG}=$ La langue gauloise 2 , par Pierre-Yves Lambert. 2003. Paris: Errance.

Macdonell, Arthur A. 1916[2000]. A Vedic Grammar for Students. Delhi: Motilal Banarsidass. 
Machek, Václav. 1968. Etymologický slovník jazyka českého. Praha: Academia.

Mayrhofer, Mannfred. 1986. Indogermanische Grammatik I.2.: Lautlehre [Segmentale Phonologie des Indogermanischen]. Heidelberg: Winter.

Mažiulis, Vytautas. 2004. Prūsu kalbos istorine gramatika. Vilnius: Vilniaus universiteto leidykla.

Melchert, H. Craig. 2012. Genitive Case and Possessive Adjective in Anatolian. In Orioles V. (ed.), Studi in ricordo. Linguistica storica e teorica per Roberto Gusmani, Vol. II, tomo 1, 273-286.

Meriggi, Piero. 1980. Schizzo gramaticale dell'Anatolico. Roma: Atti della Accademia nazionale dei Lincei, Memorie: Classe di Scienze morali, storiche e filologiche, Serie VIII, Volume XXIV, Fasc. 3.

MLH $=$ Wodtko, Dagmar \& Untermann, Jürgen. Monumenta Linguarum Hispanicarum IV: Die tartessischen, keltiberischen und lusitanischen Inschriften.

MLM $=$ de Simone, Carlo \& Marchesini Simona. 2002. Monumenta Linguae Messapicae, I-II. Wiesbaden: Reichert.

Nikolaev, Alexander. 2000. PIE ergativity and the Genitive in *osyo. In Jones-Bley, K. \& Huld, M.E. \& Della Volpe, A. (eds.), Proceedings of the Eleventh Annual UCLA Indo-European Conference, 293-309. Washington D.C.: Institute for the Study of Man (Journal of Indo-European Studies Monograph Series No. 35).

$\mathrm{NIL}=$ Wodtko, Dagmar S. \& Irslinger, Britta \& Schneider, Carolin. 2008. Nomina im indogermanischen Lexikon. Heidelberg: Winter.

Olsen, Birgit A. 1999. The Noun in Biblical Armenian. Origin and Word-Formation. Berlin-New York: Mouton de Gruyter.

Otrębski, Jan. 1956. Gramatyka języka litewskiego, Vol. III: Nauka o formach. Warszawa: Państwowe Wydawnictwo Naukowe.

Pedersen, Holger. 1907. Neues und nachträgliches. KZ 40. 129-217.

Pedersen, Holger. 1926. La cinquième déclinaison latine. København: Høst \& Søn.

Pinault, Georges-Jean. 1989. Introduction au tokharien. Paris: LALIES (Actes des sessions de linguistique et de littérature 7).

Pokorny, Julius. 1925. Altirische Grammatik. Berlin-Leipzig: Walter de Gruyter.

Rasmussen, Jens E. 1987. Aspirated tenues and Indo-European phonation series. Acta Linguistica Hafniensia 20. 81-109.

Rasmussen, Jens E. 1989. Studien zur Morphophonemik der indogermanischen Grundsprache. Innsbruck: IBS 55.

Rasmussen, Jens E. 1999. Selected Papers on Indo-European Linguistics, I-II. Copenhagen: Museum Tusculanum, University of Copenhagen.

Ringe, Don. 2006. From Proto-Indo-European to Proto-Germanic. Oxford: University Press.

Rix, Helmut. 1976. Historische Grammatik des Griechischen. Laut- und Formenlehre. Darmstadt: Wissenschaftliche Buchgesellschaft.

Savčenko, Aleksej N. 1974. Sravnitel’naja grammatika indoevropejskix jazykov. Moskva: Vysšaja škola.

Schindler, Jochem. 1975. L'apophonie des thèmes indo-européens en -r/n. Bulletin de la Société de Linguistique de Paris 70. 1-10.

Schmalstieg, William R. 1997. The Origin of the Neuter Nominative-Accusative Singular In *-OM. Journal of Indo-European Studies 25. 401-407.

Schmitt, Rüdiger. 1981. Grammatik des Klassisch-Armenischen mit Sprachvergleichenden Erläuterungen. Innsbruck: IBS 32.

Sihler, Andrew L. 1995. New Comparative Grammar of Greek and Latin. New York-Oxford: Oxford University Press.

Streitberg, Wilhelm. 1920. Gotisches Elementarbuch. Heidelberg: Winter.

Szemerényi, Oswald. 1985. Strukturelle Probleme der indogermanischen Flexion. Prinzipien und Modellfälle. In Schlerath, Bernfried \& Rittner, V. (eds.), Grammatische Kategorien. Funktion und Geschichte. Akten der VII. Fachtagung der Indogermanischen Gesellschaft (Berlin, Februar 1983), 515-533. Wiesbaden: Reichert.

Szemerényi, Oswald J. L. 1996. Introduction to Indo-European Linguistics. Oxford: Clarendon Press.

Szinnyei, Josef. 1910. Finnisch-ugrische Sprachwissenschaft. Leipzig: Göschen.

Thurneysen, Rudolf. 1946. A Grammar of Old Irish. Dublin: Institute for Advanced Studies.

Tichy, Eva. 2004. Indogermanistisches Grundwissen für Studierende sprachwissenschaftlicher Disziplinen ${ }_{2}$. Bremen: Hempen (1st edition 1999). 
Tremblay, Xavier. 2004. Die Ablautstufe des Lokativs der akrostatistischen Nomina. In Hyllested, Adam et al. (eds.), Per Aspera ad Asteriscos. Studia Indogermanica in honorem Jens E. Rasmussen, 573-590. Innsbruck: IBS 112.

UB = Urbanová, Daniela \& Blažek, Václav. 2008. Národy starověké Itále, jejich jazyky a písma. Brno: Host. de Vaan, Michiel. 2008. Etymological Dictionary of Latin and the other Italic Languages. Leiden-Boston: Brill. Watkins, Calvert. 1997. Luvo-Hittite :lapan(a)-. In Disterheft, D. et al. (eds.), Studies in Honor of Jaan Puhvel, Part I, 29-35. Washington D.C. 